\title{
Determination of Stevioside and Rebaudioside A in Stevia rebaudiana Bertoni Leaves Using near Infrared Spectroscopy and Multivariate Data Analysis
}

\author{
Yohanes Martono ${ }^{1,2}$, Suryasatriya Trihandaru ${ }^{1,2}$, and Ferdy S. Rondonuwu ${ }^{1,2, *}$ \\ ${ }^{1}$ Faculty of Science and Mathematics, Universitas Kristen Satya Wacana, \\ J. Diponegoro 52-60, Salatiga 50711, Indonesia \\ ${ }^{2}$ Research Center for Near Infrared Application and Nanotechnology, Universitas Kristen Satya Wacana \\ Jl. Diponegoro 52-60, Salatiga 50711, Indonesia
}

Received June 2, 2017; Accepted March 27, 2018

\begin{abstract}
Rebaudioside $A$ and stevioside are abundant steviol glycoside contained in Stevia rebaudiana leaves. These components are widely used as a natural sweetener. The objective of this study was to develop rapid determination method of stevioside, and rebaudioside A in S. rebaudiana leaves using near infrared trans-reflectance spectroscopy (NIRS) combined with multivariate analysis. The reference method used was HPLC. A prediction model was developed using partial least square (PLS) regression. Calibration parameters were calculated based on a calibration set of various stevioside, rebaudioside A from 23 samples. Performance of PLS model was assessed in term of optimum determination coefficient $\left(R^{2}\right)$, and minimum root mean square error of cross-validation (RMSEV). Validation of PLS model was performed using cross-validation and leave one out calibration of PLS component. Rebaudioside $A$ has well PLS model in wavenumber region of 4100-5100 $\mathrm{cm}^{-1}$, and stevioside determination using difference wavenumber region of 4760-5016 $\mathrm{cm}^{-1}$. PLS model for total (sum of stevioside and rebaudioside $A$ content) was exploited in wavenumber region of 4568-4928 $\mathrm{cm}^{-1}$. NIRS in combination with multivariate data analysis of PLSR can be applied as a rapid method for determining rebaudioside $A$ and the total amount of steviol glycosides in S. rebaudiana leaves.
\end{abstract}

Keywords: near infrared spectroscopy; PLSR; stevioside; rebaudioside A; Stevia rebaudiana

\section{ABSTRAK}

Rebaudiosida A dan steviosida adalah senyawa steviol glikosida dominan yang terkandung dalam daun Stevia rebaudiana. Senyawa tersebut banyak digunakan sebagai pemanis alami. Tujuan penelitian ini adalah mengembangkan metode penetapan kadar setiosida dan rebaudiosida A dalam daun S. rebaudiana menggunakan spektroskopi Near Infrared (NIRS) trans-reflektan yang dikombinasi dengan analisis multivariat. Sebagai metode referens adalah HPLC. Model prediksi yang dikembangkan menggunakan regresi Partial Least Square (PLS). Parameter kalibrasi dihitung berdasarkan sejumlah 23 sampel kalibrasi set yang bervariasi kandungan steviosida dan rebaudiosida A-nya. Model PLS yang optimal ditentukan berdasarkan koefisien determinasi $\left(R^{2}\right)$ dan root mean square error of cross-validation (RMSEV) yang minimum. Validasi model menggunakan model cross validation dan leave one out dari komponen PLS. Model PLS rebaudiosida A dikembangkan pada daerah bilangan gelombang $4100-5100 \mathrm{~cm}^{-1}$ dan steviosida pada daerah bilangan gelombang yang lain yaitu 4760-5016 $\mathrm{cm}^{-1}$. Model PLS untuk jumlah steviol glikosida dominan dibangun pada daerah bilangan gelombang 4568-4928 $\mathrm{cm}^{-1}$. Metode spektroskopi NIR yang dikombinasi dengan analisis multivariat dapat digunakan sebagai metode penetapan kadar steviosida dan rebaudiosida A serta jumlah totalnya dalam daun S. rebaudiana secara cepat.

Kata Kunci: spektroskopi near infrared; PLSR; stevioside; rebaudiosida A; Stevia rebaudiana

\section{INTRODUCTION}

Rebaudioside and stevioside are two major steviol glycosides in Stevia rebaudiana leaves. These compounds are widely used as a natural sweetener in Australia, Argentina, Brazil, China, India, Japan, New Zealand, Paraguay, Russia, South Korea and other countries [1-2]. Rebaudioside A and stevioside also have important bioactivities as antidiabetic agent [3]; antioxidant [4] and anticancer [5]. Dealing with economic values and safety, several regulations have been applied in various countries [6]. Every regulation focuses on a quantitative aspect of respected compounds.

* Corresponding author. Tel : +62-81390000149

DOI: $10.22146 /$ ijc.25580

Email address : ferdy@staff.uksw.edu

Yohanes Martono et al. 


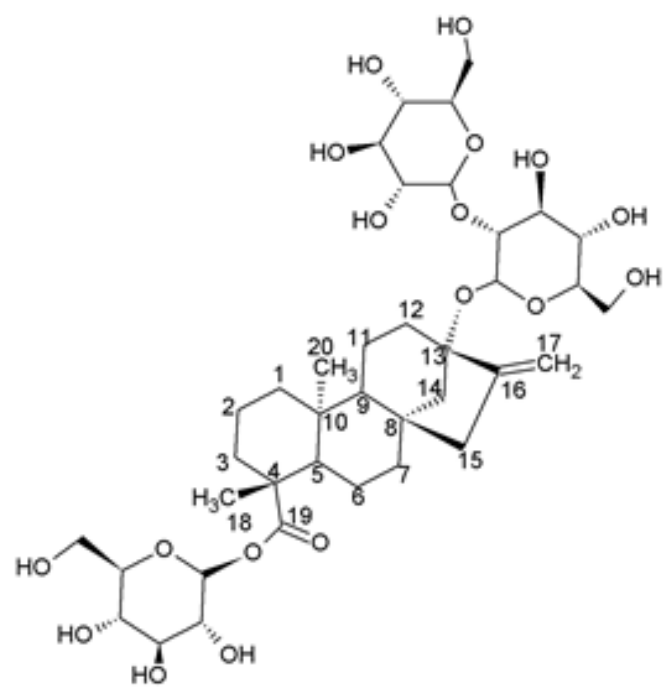

(a)

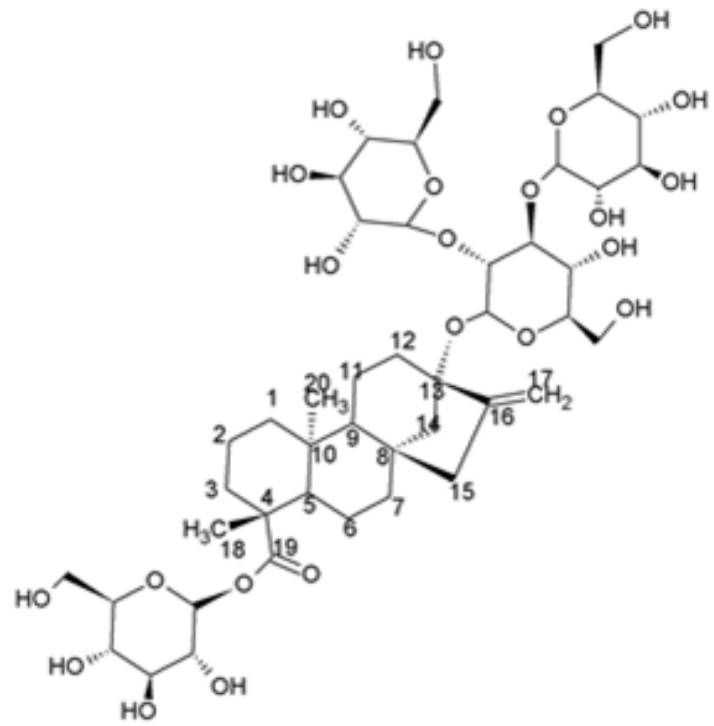

(b)

Fig 1. The molecular structure of stevioside (a) and rebaudioside A (b)

Various methods have been reported to determine rebaudioside $A$ and stevioside. The challenge to develop the method was the similarity structure of stevioside and rebaudioside $A$ which is different only in glucose attached at $\mathrm{C}-13$ (Fig. 1). The polarity of Stevioside A is slightly higher than that of stevioside. Most of the methods reported based on HPLC method [1-2,6-11]. However, HPLC method is still costly, need a long time to analyze, high consume on solvents and unpracticed in sample handling.

Vibrational spectroscopy methods have been developed to determine rebaudioside $A$ and stevioside. FTIR method in combination with multivariate data analysis of partial least square regression (PLSR) has been reported to determine respected compounds in $S$. rebaudiana leaves and Stevia beverages simulation [12-13]. However, the method developed still need solvent extraction and drying for sample preparation. Near Infrared spectroscopy (NIRS) method in combination with chemometric of PLS also have been reported [14-16]. However, the NIRS methods developed still unclear in simultaneous determination of rebaudioside $A$ and stevioside in one wavenumber region. The methods reported previously applied separate calibration to establish PLS model. Yu et al. [15] has been reported simultaneous determination of stevioside and rebaudioside $A$ in $S$. rebaudiana leaves. Unfortunately, the research by $\mathrm{Yu}$ et al. [15] did not report performance of PLS model established in term of determination coefficient $\left(R^{2}\right)$, root mean square error of calibration (RMSEC) and root mean square error of prediction (RMSEP) as reliability model developed. This research aims to improve rapid NIRS method combined with multivariate data analysis of PLS to establish PLS model whether separate or simultaneous calibration of stevioside, rebaudioside A, and total steviol glycosides. The method developed was carried out without significant sample preparation.

\section{EXPERIMENTAL SECTION}

\section{Materials}

S. rebaudiana leaves $(n=23)$ were obtained from P.T. Java Sakti Niaga plantation spread in some high hills in Central Java, Indonesia including Poloboga, Tajuk, Pakis, and Bandungan. S. rebaudiana leaves from Tawangmangu was obtained from Stevia farmer in the local area. The harvested S. rebaudiana leaves have diversity on the different growing area, ages of leaves, and cultivar which was determined by Department of Biology, Faculty of Pharmacy, Universitas Gadjah Mada, Indonesia under taxonomist supervision of Drs. Djoko Santosa, M.Si. This diversity was sufficient to meet various content of analyte for optimizing PLS model.

Rebaudioside $A$ and stevioside standard were purchased from WAKO, Japan with purity of $99.8 \%$ for both standards according to the certificate of analysis. Acetonitrile and methanol (HPLC grade) for HPLC mobile phase, ethanol (pro analysis grade) for sample extraction in HPLC analysis were purchased from $\mathrm{E}$. Merck, Germany. Water (distilled water) was obtained from Laboratory of Chemistry Department, Faculty of Science and Mathematics, Satya Wacana Christian University. 


\section{Instrumentation}

HPLC used was the HPLC Knauer GmBH-Jerman Smart Line Series model with UV detector (Smart Line UV Detektor 2500 A 5140), Smart Line Pump 1000 V 7603 and Rheodyne Loop model A1357 for sample injector. The column used was Eurosphere C-18 (250 x $4.6 \mathrm{~mm}$ i.d, $5 \mu \mathrm{m}$ ) with guard column The NIR spectrophotometer used was NIRFlex N-500, BUCHI, Switzerland in diffused reflectance mode.

\section{Procedure}

\section{HPLC analysis}

Fresh $S$. rebaudiana leaves were separated from rots plant and dried under $50{ }^{\circ} \mathrm{C}$ for $48 \mathrm{~h}$ in cabinet dryer. Dried leaves were ground into a fine powder of 60 mesh particle size. The dried powders of $S$. rebaudiana leaves were stored in labeled screwed bottle sample and were then kept in a refrigerator at $4{ }^{\circ} \mathrm{C}$ until HPLC and NIR analysis.

Sample extraction conducted was referred to Martono et al. [8] method. A $0.5 \mathrm{~g}$ of each dried powder $S$. rebaudiana leaves were weighed and extracted three times with $25 \mathrm{~mL}$ ethanol $60 \%(\mathrm{v} / \mathrm{v})$ in every extraction using sonication extraction at $40{ }^{\circ} \mathrm{C}$ for 15 min every extraction cycle. Filtrates were collected and added to $100 \mathrm{~mL}$ extraction solvent in a volumetric flask. The sample solution was filtered using microfilter of $0.45 \mu \mathrm{m}$ before injected in HPLC system.

Method for HPLC analysis was explained in previous publications by Martono et al. [8]. HPLC analysis was conducted on Eurosphere C-18 (250 x $4.6 \mathrm{~mm}$ i.d, $5 \mu \mathrm{m}$ ) with guard column. The mobile phase used was the mixture of water:methanol $(90: 10, \mathrm{v} / \mathrm{v}$, adjusted in $\mathrm{pH} 3.0$ with phosphoric acid) (solvent $A$ ) and acetonitrile (solvent $B$ ). Solvent $A$ was mixed with solvent $B$ in a ratio of $A: B=65: 35(\mathrm{v} / \mathrm{v})$. The mixture was then added with trifluoroacetic acid $0.01 \%(\mathrm{v} / \mathrm{v})$. Elution was carried out in isocratic elution using mobile phase flow rate applied of $0.6 \mathrm{~mL} / \mathrm{min}$. Detection was performed with UV detector at $\lambda 210 \mathrm{~nm}$. An injection volume of injector loop used was $20 \mu \mathrm{L}$.

\section{NIR acquisition}

Dried powder of $S$. rebaudiana leaves $(n=23)$ was placed in a vial. Samples in vial were then put into the sample holder. NIR spectra were recorded at full wavenumber region of the instrument, i.e., 4000-10000 $\mathrm{cm}^{-1}$ in trans-reflectance mode at room temperature although only at specific wavenumber region was used (vide infra). Each spectrum was measured in $4 \mathrm{~cm}^{-1}$ data intervals and averaged over 32 scans with ceramic as reference to blank sample.

\section{Multivariate data analysis}

Multivariate data analysis used for NIR spectra was PLS regression model. In this case, PLS defines a most informative orthogonal latent variable and explicitly construct such latent variable to capture variance in NIR matrix data to HPLC reference data. In general, NIR spectra measured in trans-reflectance mode exhibits random multiplicative scattering and baseline variations. Since random variations strongly affect PLS calculation, then pre-processing spectra were applied prior PLS calculations. In this analysis, MATLAB ${ }^{\circledR}$ was employed during pre-processing and PLS calculations. Baseline variations and multiplicative scattering effects were removed by taking the $1^{\text {st }}$ derivative of the raw spectral data while the spectral resolution was improved by the $2^{\text {nd }}$ derivative. SavitzkyGolay smoothing with polynomial order 3 at frame length 19 were applied before the $1^{\text {st }}$ and $2^{\text {nd }}$ derivatives. PLS model was then calculated based on $2^{\text {nd }}$ derivative spectra. In PLS model using crossvalidation method, 23 samples were split into two groups; the $1^{\text {st }}$ group called calibration set consists of 12 sample while the $2^{\text {nd }}$ group of 11 samples was used as a validation set.

Another cross-validation technique applied was leave on out method. In this technique, one sample out of 23 was removed for validation based on the remaining 22 samples that were used for generating calibration parameters. This procedure was repeated until each of data were used for validation. Both sample split and leave one out techniques seek for minimum root mean square error of cross-validation (RMSEV) at highest determination coefficient $\left(R^{2}\right)$ by carefully evaluated the number of components used to develop PLS calibration curve. The value used for reference was taken by HPLC analysis for stevioside, rebaudioside $A$ and the total amount of main steviol glycosides.

\section{RESULT AND DISCUSSION}

\section{HPLC and NIR Analysis}

HPLC analysis was used as reference method which generated actual value for PLS model development. Chromatogram of HPLC analysis showed complete separation of rebaudioside $A$ and stevioside peak in good resolution $(R>2.00)$ (Fig. 2). High resolution of analytic peak makes area converted concentration calculation become reliable, accurate and precise. NIR spectra (Fig. 3(a)) showed some inverted peak revealed at $4000-6500 \mathrm{~cm}^{-1}$. In general, peak at a wavenumber of $4000-6250 \mathrm{~cm}^{-1}$ is correlated to main targeted compounds while the peak at a 


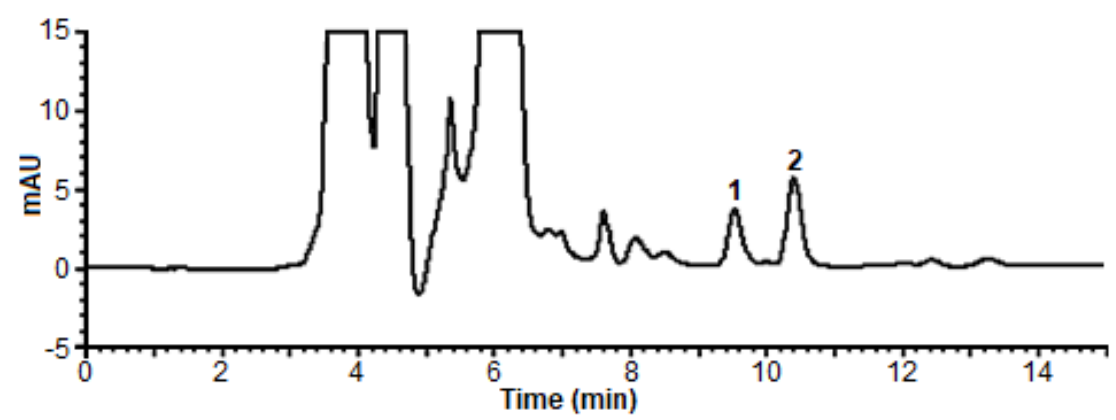

Fig 2. Chromatogram of S.rebaudiana leaves from Gedongsongo, Bandungan, Central Java, Indonesia. Rebaudioside A ( $\mathrm{tR}=9.615 \mathrm{~min})(1)$ and stevioside $(\mathrm{tR}=10.589 \mathrm{~min})(2)$
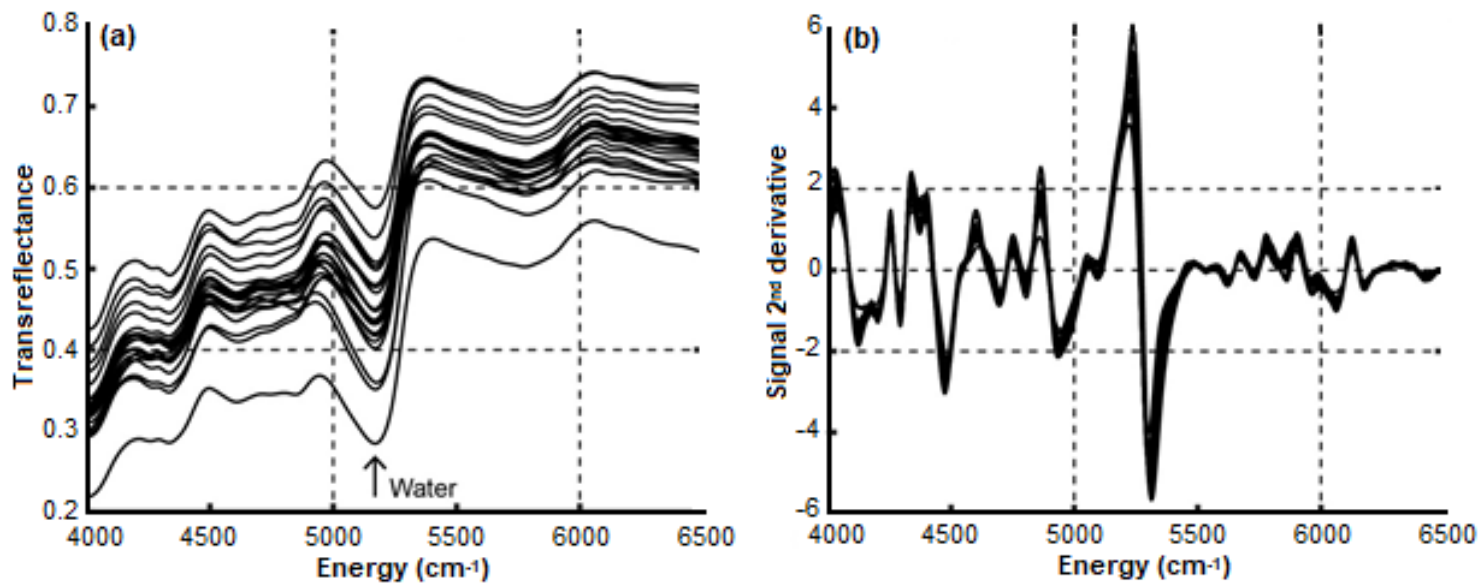

Fig 3. (a) Trans-reflectance spectra of dried stevia leaves from the various growing area, ages of leaves, and cultivar. Note that each spectrum has a different baseline. Strong absorption of water is indicated by arrows. (b). The second derivative of the trans-reflectance spectra after normalization. The baseline variations have been omitted in the first derivation. The sharp peaks indicate the minimum positions of the corresponding trans-reflectance spectrum

wavenumber of $6250-10000 \mathrm{~cm}^{-1}$ is correlated to water peak [15]. Stevioside and rebaudioside A have abundant $\mathrm{C}-\mathrm{H}$ and $\mathrm{O}-\mathrm{H}$ bond in its molecular structure. These bonds have strong vibration absorption and produce significant interaction between radiations with compounds contained. The transmittance at a wavenumber of $4000-5000 \mathrm{~cm}^{-1}$ is correlated to combination state of $\mathrm{C}-\mathrm{H}$ and $\mathrm{O}-\mathrm{H}$ bond [17]. Particularly, the transmittance at a wavenumber of around $4200-4300 \mathrm{~cm}^{-1}$ showed the interaction of $\mathrm{CH}_{2}$ bend second overtone in the glycosyl [18]. Moreover, the transmittance at a wavenumber of $5500-6250 \mathrm{~cm}^{-1}$ showed the interaction of the first overtone of $\mathrm{C}-\mathrm{H}$ bond while wavenumber of $5900-7500$ is correlated to the second overtone of $\mathrm{O}-\mathrm{H}$ bond [17]. NIR spectra exhibit baseline variation and their absorptions band appear as broad peak due to overtone, and combination vibration overlapped almost in the same wavenumber region. To overcome those two limitations, the NIR spectra were derived twice; the $1^{\text {st }}$ derivative applied for baseline variations removals while the second derivative was applied for improving spectral resolution. The result of $2^{\text {nd }}$ derivative spectra is shown in Fig. 3(b). Note that NIR raw spectra were normalized without centering before the $1^{\text {st }}$ derivation. All PLS calculations were performed using $2^{\text {nd }}$ derivative spectra.

\section{PLS Model Development}

\section{Separate calibration of rebaudioside A, stevioside and total steviol glycosides}

Wavenumber selection is a critical point in PLS development. Certain wavenumber region of NIR spectra gave specific information of variables to establish PLS model. Screening frequencies applied becomes significant step to obtain optimum PLS model [12]. In separate calibration, there were different frequencies applied to establish PLS model (Table 1). Rebaudioside $A$ has well PLS model in wavenumber region of $4100-5100 \mathrm{~cm}^{-1}$. Rebaudioside $A$ has a strong interaction with NIR radiation in combination with $\mathrm{C}-\mathrm{H}$ bond and $\mathrm{CH}_{2}$ bend second overtone in glycosyl molecular structure [17-18]. PLS model of rebaudioside $A$ established at the same wavenumber as 
Table 1. Comparison between PLS model developed in previous study to proposed PLS model in recent study

\begin{tabular}{llllll}
\hline $\begin{array}{l}\text { Reported } \\
\text { research }\end{array}$ & Steviol glycoside & $\begin{array}{l}\text { Wavenumber } \\
\text { region }\left(\mathrm{cm}^{-1}\right)\end{array}$ & $\mathrm{R}^{2}$ & RMSEC & RMSEP \\
\hline Recent study & rebaudioside A & $4100-5100$ & 0.60 & 0.16 & 0.98 \\
$(\mathrm{~N}=5)$ & stevioside & $4760-5016$ & 0.78 & 0.97 & 1.63 \\
& total & $4568-4928$ & 0.87 & 0.31 & 1.63 \\
Hearn and & stevioside & $4367-4452$ & 0.80 & 0.80 & - \\
Subedi [14] & total & $4464-4897$ & 0.93 & 0.68 & - \\
Tang et al. [16] & stevioside & - & 0.969 & 3.42 & 4.31 \\
& rebaudioside A & - & 0.934 & 3.93 & 4.33 \\
\hline
\end{tabular}
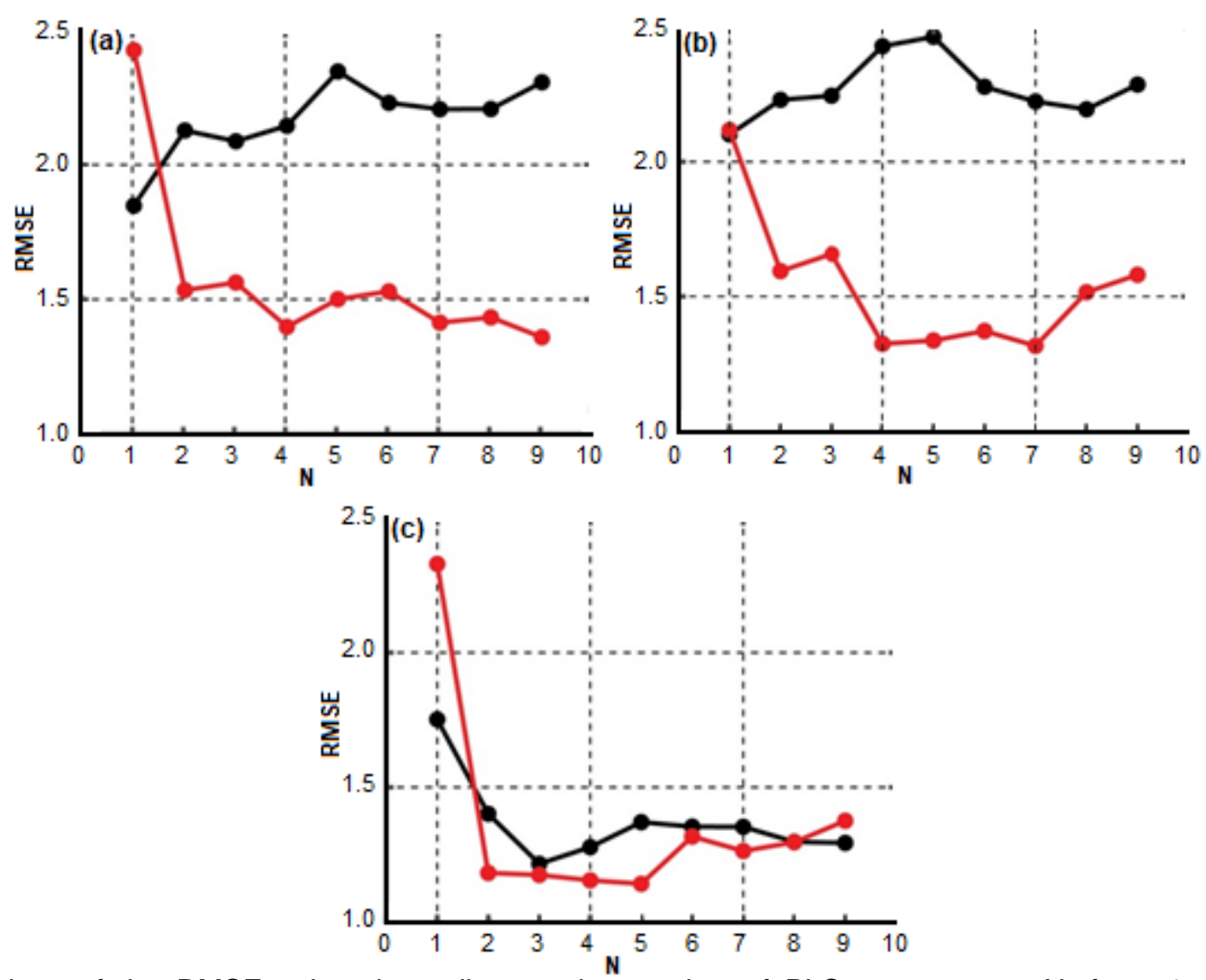

Fig 4. Variations of the RMSE value depending on the number of PLS components, N, from 1 to 10 for (a) Rebaudioside A, (b) Stevioside, and (c) Total main steviol glycosides. The Red bullet represents the validation data set (RMSEV) whereas the black one represents the calibration data set (RMSEC)

mentioned above successfully revealed linear regression correlation between actual value vs. predicted value with $\mathrm{R}^{2}$, RMSEC, and RMSEP of $0.60,0.16$ and 0.98 , respectively (Table 1 ). This result is comparable to PLS model developed previously by Hearn and Subedi [14] and Tang et al. [16] (Table 1).

PLS model for stevioside determination using difference wavenumber region to obtain the optimum model. Three wavenumber region of $4760-5016 \mathrm{~cm}^{-1}$, were used to establish the PLS model. The wavenumber of $4760-5016 \mathrm{~cm}^{-1}$ correlated to combination band of $\mathrm{C}-\mathrm{H}$ and $\mathrm{O}-\mathrm{H}$ bond and also $\mathrm{CH}_{2}$ bend second overtone in glycosyl (4024-4688 $\left.\mathrm{cm}^{-1}\right)$, and combination of $\mathrm{O}-\mathrm{H}$ stretching and bending $\left(\sim 5000 \mathrm{~cm}^{-1}\right)$. In addition, first overtone of $\mathrm{C}-\mathrm{H}$ bond located at wavenumber region of 5600-5768 $\mathrm{cm}^{-1}$ [17-18]. Hearn and Subedi [14] used wavenumber of $4367-4452 \mathrm{~cm}^{-1}$ to establish PLS model for stevioside determination. Yu et al. [15] reported wavenumber of $4035-6934 \mathrm{~cm}^{-1}$ to determine stevioside and rebaudioside $A$ in $S$. rebaudiana leaves using PLS model. The capacity of PLS model for stevioside determination revealed $\mathrm{R}^{2}$, RMSEC, and RMSEP of $0.78,0.97$, and $1.63 \%$, respectively. This result is similar to previous PLS model established by Hearn and Subedi [14] and Tang et al. [16] (Table 1). 

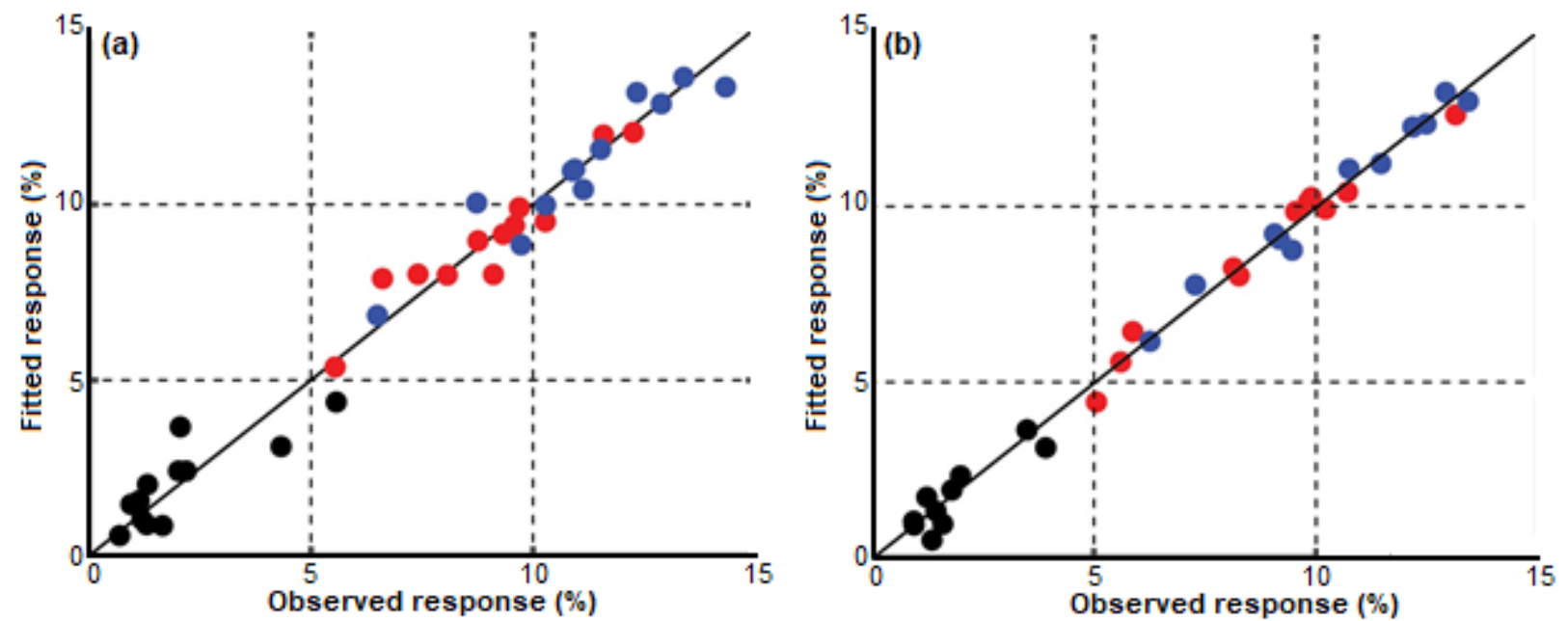

Fig 5. Comparison between observed and fitted response using cross-validation method for (a) calibration, (b) crossvalidation. Rebaudioside A (black), Stevioside (red) and Total main steviol glycosides (blue). PLS parameters was constructed with a number of components, $\mathrm{N}=4$

PLS model for total (sum of stevioside and rebaudioside $A$ content) was exploited in wavenumber region of 4568-4928 $\mathrm{cm}^{-1}$. Hearn and Subedi [14] applied different wavenumber region of $4464-4897 \mathrm{~cm}^{-1}$ to establish PLS model for the total combination of stevioside, rebaudioside $\mathrm{C}$ and rebaudioside $\mathrm{A}$ concentration. The capacity of PLS model established showed $R^{2}$, RMSEC, and RMSEP of $0.87,0.31$, and 1.47 , respectively. This result is similar to the result obtained from the previous study (see Table 1).

\section{Simultaneous calibration of rebaudioside stevioside, and total steviol glycosides}

The optimization of PLS model for simultaneous calibration of stevioside, rebaudioside $A$ and total steviol glycoside in effective wavenumber region are challenging. Similar structures of both compounds make similar interaction with near infrared radiation. However, there are no exactly same spectra resulted in vibrational spectroscopy since each compound in the sample would interact uniquely with near infrared radiation [19]. The optimum PLS model established exploited single wavenumber region of $4000-6500 \mathrm{~cm}^{-1}$ although previous research applied different wavenumber region of 4035-6934 $\mathrm{cm}^{-1}$ [15] to the simultaneous determination of stevioside and rebaudioside A. PLS regression not only sensitive to a particular region but also a number of components, N, used to calculate PLS parameters. To evaluate best $\mathrm{N}$ for PLS model, PLS calculations were performed using $\mathrm{N}=1-10$ and monitor both root mean square error of calibration (RMSEC) and RMESV. Fig. 4a-c show evolutions of RMSEC and RMSEV when $\mathrm{N}$ was systematically tuned from 1 to 10 . As expected, RMSEC will decrease when $\mathrm{N}$ increases. However RMSEV will achieve their minimum at particular $\mathrm{N}$. It is obvious that minimum RMSEV is given by $\mathrm{N}=4$ for rebaudioside $\mathrm{A}$, stevioside, and total steviol glycosides. One may notice, however, taking $\mathrm{N}$ $=5$ for total steviol glycosides will give slightly smaller RMSEV with predicted residual sum of squares (PRESS) $=19.6$ and 22.0 for $\mathrm{N}=5$ and 4 , respectively .

PLS calculations were performed using second derivative spectrum in the wavenumber region of $4000-6500 \mathrm{~cm}^{-1}$ using $\mathrm{N}=4$. Calibration and validation sets use HPLC results as references. Those references consist of three responses (in \%) including Rev-A, Stevia, and total main steviol glycosides. These three references data were simultaneously used as response parameters in the calculation of simultaneous calibration models. To evaluate the performance of the calibration parameters, the resulted parameters were tested to the same data set. The result is shown in Fig. 5a. The calibration parameters are performed well as indicated by the good consistency between the prediction responses and actual responses. The resulted calibration model was then applied to the validation data set (thus, cross-validated) to simultaneously predict the content of rebaudioside $A$, stevioside, and total main steviol glycosides. Prediction coefficients $\left(R^{2}\right)$ for Stevioside $A$, stevioside, and total main steviol glycosides determinations were $0.12,0.85$ and 0.90 , respectively. Comparison between prediction and actual responses is fairly good for stevioside, and total main steviol glycosides although poor for rebaudioside $A$ determination as depicted in Fig. $5 \mathrm{~b}$. For comparison, leave one out method was also performed using the number of component $\mathrm{N}=4$. In this method, 1 sample was taken out for validation while the rest was used to construct the calibration parameter. This method was repeated until each sample 


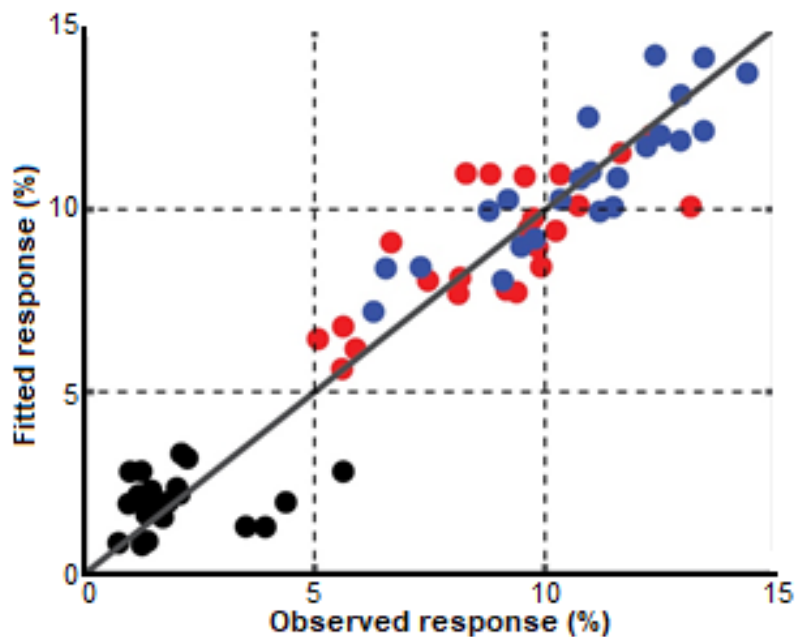

Fig 6. Comparison between observed and fitted response using leave one out method with a number of components, $N=4$, for determination of stevioside $A$ (black), stevioside (red) and total main steviol glycoside (blue) content

is validated. The accuracy of the leave one out method is shown in Fig. 6. Validation results using leave one out method appear to be no better than the cross-validation method although good coefficient determination $\left(\mathrm{R}^{2}=\right.$ 0.77 and 0.88 for stevioside, and total main steviol glycosides, respectively) is also achieved. Both crossvalidation and leave one out methods suggest that NIRS measurement with PLS calibration model can predict stevioside, and total main steviol glycosides content in dry stevia leaves under carefully select spectral region and critically chose a number of component in PLS calculations. However, the determination of rebaudioside A should be determined separately.

\section{CONCLUSION}

Near infrared spectroscopy combined with multivariate data analysis was successfully generated PLS model to determine stevioside, and total steviol glycoside separately or simultaneously intact to $S$. rebaudiana leaves. The developed method is rapid, efficient, and reliable to be applied as a quality control technique. Determination of rebaudioside $A$ need to developed further employing larger sample number and carefully select the effective wavenumber region.

\section{ACKNOWLEDGEMENT}

We wish to thank Ministry of Research, Technology, and Higher Education Indonesia for funding this research by Fundamental Research Grant year 2016 and Universitas Kristen Satya Wacana for funding this publication.

\section{REFERENCES}

[1] Kolb, N., Herrera, J.L., Ferreyra, D.J., and Uliana, R.F., 2001, Analysis of sweet diterpene glycosides from Stevia rebaudiana: Improved HPLC method, J. Agric. Food Chem., 49 (10), 4538-4541.

[2] Woelwer-Rieck, U., Lankes, C., Wawrzun, A., and Wüst, M., 2010, Improved HPLC method for the evaluation of the major steviol glycosides in leaves of Stevia rebaudiana, Eur. Food Res. Technol., 231 (4), 581-588.

[3] Gregersen, S., Jeppesen, P.B., Holst, J.J., and Hermansen, K., 2004, Antihyperglycemic effects of stevioside in type 2 diabetic subjects, Metabolism, 53 (1), 73-76.

[4] Kim, I.S., Yang, M., Lee, O.H., and Kang, S.N., 2011, The antioxidant activity and the bioactive compound content of Stevia rebaudiana water extracts, LWT Food Sci. Technol., 44 (5), 13281332.

[5] Takasaki, M., Konoshima, T., Kozuka, M., Tokuda, H., Takayasu, J., Nishino, H., Miyakoshi, M., Mizutani, K., and Lee, K.H, 2009, Cancer preventive agents. Part 8: Chemopreventive effects of stevioside and related compounds, Bioorg. Med. Chem., 17 (2), 600-605.

[6] Well, C., Frank, O., and Hofmann, T., 2013, Quantitation of sweet steviolglycosides by means of a HILIC-MS/MS-SIDA approach, J. Agric. Food Chem., 61 (47), 11312-11320.

[7] Bergs, D., Burghoff, B., Joehnck, M., Martin, G., and Schembecker, G., 2012, Fast and isocratic HPLC-method for steviol glycosides analysis from Stevia rebaudiana leaves, J. Verbrauch. Lebensm., 7 (2), 147-154.

[8] Martono, Y., Riyanto, S., Rohman, A., and Martono, S., 2016, Improvement method of fast and isocratic RP-HPLC analysis of major diterpene glycoside from Stevia rebaudiana leaves, AIP Conf. Proc., 1755 (1), 80001.

[9] Dacome, A.S., da Silva, C.C., da Costa, C.E.M., Fontana, J.D., Adelmann, J., and da Costa, SC., 2005, Sweet diterpenic glycosides balance of a new cultivar of Stevia rebaudiana (Bert.) Bertoni: Isolation and quantitative distribution by chromatographic, spectroscopic, and electrophoretic methods, Process Biochem., 40 (11), 3587-3594.

[10] Cacciola, F., Delmonte, P., Jaworska, K., Dugo, P., Mondello, L., and Rader, J.I., 2011, Employing ultra high pressure liquid chromatography as the second dimension in a comprehensive twodimensional system for analysis of Stevia rebaudiana extracts, J. Chromatogr. A, 1218 (15), 2012-2018. 
[11] Jaworska, K., Krynitsky, A.J., and Rader, J.I., 2012, Simultaneous analysis of steviol and steviol glycosides by liquid chromatography with ultraviolet detection on a mixed-mode column: Application to stevia plant material and stevia-containing dietary supplements, J. AOAC Int., 95 (6), 1588-1596.

[12] Martono, Y., 2016, Quantitative Chemical Analysis Study of Stevioside and Rebaudioside A from Stevia rebaudiana Bertoni Leaves And Stevia Beverages Simulation Product, Dissertation, Faculty of Pharmacy, Universitas Gadjah Mada, Yogyakarta, 164-189.

[13] Martono Y., Riyanto, S., Martono, S., and Rohman, A., 2016, Determination of stevioside and rebaudioside a from simulated stevia beverages using FTIR spectroscopy in combination with multivariate calibration, Res. J. Med. Plants, 10 (5), 349-355.

[14] Hearn, L.K., and Subedi, P.P., 2009, Determining levels of steviol glycosides in the leaves of Stevia rebaudiana by near infrared reflectance spectroscopy, J. Food Compos. Anal., 22 (2), 165168.
[15] Yu, C., Xu, K., and Shi, Y., 2011, The spectrum model established for measuring the contents of rebaudioside $A$ and stevioside quickly in the leaves of Stevia rebaudiana Bertoni, Energy Procedia, 5, 855-861.

[16] Tang, Q.K., Min, D., Hu, T., Kai, G., and Wang, Y., 2014, Determination of the content of steviol glycoside in Stevia rebaudiana by Near Infrared Spectroscopy (NIRS), Med. Plants, 5 (4), 33-35.

[17] Bokobza, L., 2001, "Origin of Near-Infrared Absorption Bands" in Near-Infrared Spectroscopy, Eds., Siesler, H.W, Ozaki, Y., Kawata, S., and Heise, H.M., Wiley-VCH, Verlag GmbH, 11-41.

[18] Li, W., Xing, L., Cai, Y., and Qu, H., 2011, Classification and quantification analysis of Radix scutellariae from different origins with near infrared diffuse reflection spectroscopy, Vib. Spectros., 55 (1), 58-64.

[19] Rohman, A., Setyaningrum, D.L., and Riyanto, S., 2014, FTIR spectroscopy combined with partial least square for analysis of red fruit oil in ternary mixture system, Int. J. Spectros., 2014, 785914, $1-5$. 